\title{
The Ballads of Uladzimir Arloŭ
}

\author{
BY
}

ARNOLD McMILLIN

\author{
Uladzimir Arloŭ \\ padručnik Piatrovič i praparščyk Zdań. \\ Minsk: Bielaruski knihazbor, 2018. 130 s. \\ ISBN: 978-985-7180-95-0
}

A new book by Uladzimir Arloŭ (b. 1953) is always a notable event. He needs no introduction as the leading Belarusian historical novelist of the second half of the twentieth century, and renowned essayist as well as, in recent years, poet. In 2018 he won the coveted Giedroyc prize for his book of novellas, Tancy nad horadam (Lohvinaŭ, 2017), and in his latest book he presents a range of narrative poems, all written with a lightness of touch and his characteristic sense of humour, already indicated in the title.

There are nine sections, not all of which are ballads in any conventional sense of the word,but are without exception highly entertaining and imaginative free-verse, unrhymed narratives. The first, Kat Baltazar (Butcher Balthazar), is described as a Polacak ballad, and has a third-person narrator. As a child Balthazar had helped Sobieski to save Europe from the Turks at the battle of Vienna, and later defended Polacak from various enemies. Combining lust with sadism, he veers between two women, eventually seeming to tire of these activities, instead replying to a phone call from America, before returning to the novel about contemporary love he is writing on his computer. This complete lack of chronology is simply the first example of something that is common throughout this remarkable book.

The next section, Arkady Padui (The Arcades of Padua, 2007) is not so much a ballad as a rumbustious guide to the past and present of the Italian city. As in several later parts of the book, the protagonist is addressed in the second person as "Ty". As always with Arloŭ, his robust masculine humour, as well as broad learning make his account of Padua, not least, of course, Skaryna's stay there, both amusing and informative. As in all his non-historical prose and verse, this writer's thoughts are never far from his native country. For instance, a medical theatre reminds him of the white-red-white flag (p. 14), and he compares the manner Livy is reported 
to have prepared eggs with that which is popular in Polacak (pp. 12-13). The guide contains a huge array of historical characters, a prodigious amount of fantasy, much of it sexual, and, amongst it all, constant evidence of the author's lively enquiring nature.

Most of the other sections are also concerned with places and countries. Alieka (Aleko), a Balkan ballad, set mainly in Bulgaria, begins with two rude words written in the snow which may be considered the first line of a poem; in this ballad, the poet has been invited to receive the Aleko Konstantinov prize, and assigned an attractive young interpreter, Pienka, who believes that Bulgarians founded Kiyiv, and that Romanians are really Bulgarians who, being on the other side of the Danube, are forbidden to speak their native language. The poet, however, gives most space to Stalin's murderous politics in Belarus, and to a monument to Bulgarian support for Hitler during the war. He also finds another monument to the eponymous poručnik Piatrovič and praparščik Zdań, who play a small role in this complex ballad. On the train home he meets Russian guards who are drunk, simple minded and foulmouthed, like all the Russians in Arloŭ's ballads.

Sura Sheinblit (2009), is mainly about the Jewish town of Berdichev in Ukraine, and its other inhabitants or visitors including Conrad, Balzac and Shelley; a refrain in this ballad is "Were you not a Jew when you were a child?" (pp. 60).

Vulica Salamieja (Salome Street, 2017), a Galician ballad, is set mainly in Lviv. Unsurprisingly in view of the Ukrainian war, it is, in addition to the by now familiar literary and cultural fantasies, rich in criticism of Russia's bellicosity. Other characters in addition to Salome are Alena Kiš (1889-1949, a Belarusian primitive painter), Oksana Zabužko and her book Fieldwork in Ukrainian Sex, as well as Bruno Schulz and his murderer Karl Günter, while Nostradamus and Bandera also attend the narrator's poetic reading.

Apošniaja žančyna Kazanovy (The Last Woman of Casanova, 2017) is described as a Bohemian ballad. The woman of the title is Darota aged twenty-one, and Arloŭ mentions some of the famous lover's male visitors from Benjamin Franklin to Mozart. Darota, for her part, devises a wonderful revenge on Casanova for when he is sixty-six.

Hvirabi is a Georgian ballad named after the celebrated local white wine, Gvirabi. Knut Hamsun, notorious for his open admiration for Hitler, died there, but does not want to remain in his grave. The poet wonders whether there are any Norwegian writers without graves, noting that the right-wing murderer Anders Breivik is still in prison. Other famous visitors and exiles that come to the poet's mind include the poet Tadeusz Łada Zabłocki and Russian playwright Aleksandr Griboedov, but it is a later Russian presence that seems uppermost 
in Arloŭ's narrative, alongside women and drinking, when he declares that no treaty with Russia is worth the paper it is written on, and laments the destruction of a 1500-year-old chapel that had been turned into a prison and all its frescoes destroyed. This ballad is particularly rich in a technique also found elsewhere, namely the repetition of lines and ideas (somewhat like the leitmotivs in Wagner's operas).

Earlier in the book, a more straightforwardly autobiographical piece, Miod (Honey), begins with a reminiscence of eating bread and honey with slightly older friends, two boys and a girl, Ninka, when he was twelve. The question arises, not for the last time, of his having a gypsy grandfather, while they eat on plates decorated with a swastika (his grandmother remembers having a wartime friend Paul). As the honey rolls down Ninka's front, the poet reflects on the dangers and pleasures of looking at women's breasts and the rumour that it may extend a man's life by five years. Later in what is probably the most straightforward narrative in the book, forty-three years after that honey, the poet suffers a heart attack, and wonders whether he had not ogled sufficiently, although, as he wryly observes, enough to survive; he has moreover drunk three times more from a mug with an eagle and swastika than his doctors would allow (p. 31).

The last section of the book is Paetyčny fest u Druskienikach (A Poetic Festival in Druskininkai). The leitmotiv here is "your organism is poisoned by poetry" (p. 116), and among delegates' discussions are the worth or otherwise of the Nobel Prize, and whether a Spaniard's poems about Barcelona should acknowledge that it is not Spain but Catalonia. A Japanese poetess recites a poem against all -isms; a sarcastic Croatian announces a poem Cišynia (Quiet) and then remains silent; and a Lithuanian reads a brutal poem about the Magi who find the infant Jesus in a plastic bag in a container, but leave him there for fear of trouble with the police, to suffer for our sins. The chaotic end of the conference comes with the appearance of a host of people from a variety of countries and historical eras. The final words, sung by the band Ben Jovi, are:

\section{'It's all the same \\ Only the names have changed'.}

Arloŭ's latest book will delight many readers, particularly those who share his delight in a stream of postmodern wordplay and broken chronology, and immense historical curiosity, even those who are taken aback by some of the bawdy humour. It serves as a reminder, if such be needed, of the variety and richness of contemporary Belarusian literature. 